Int. J. Electrochem. Sci., 14 (2019) 10607 - 10621

International Journal of

ELECTROCHEMICAL

SCIENCE

$\underline{\text { www.electrochemsci.org }}$

\title{
Voltammetric Determination of Bisphenol A in the Presence of Uric Acid Using a Zn/Al-LDH-QM Modified MWCNT Paste Electrode
}

Nurashikin Abd Azis ${ }^{1}$, Illyas Md Isa ${ }^{1,2, *}$, Norhayati Hashim ${ }^{1,2}$, Mohamad Syahrizal Ahmad ${ }^{1,2}$, Siti Nur Akmar Mohd Yazid ${ }^{1}$, Mohamad Idris Saidin ${ }^{1}$, Suyanta M. Si ${ }^{3}$, Rahadian Zainul, Alizar Ulianas $^{4}$, Siriboon Mukdasai ${ }^{5}$

${ }^{1}$ Department of Chemistry, Faculty of Science and Mathematics, Universiti Pendidikan Sultan Idris, 35900 Tanjong Malim, Perak, Malaysia

${ }^{2}$ Nanotechnology Research Centre, Faculty of Science and Mathematics, Universiti Pendidikan Sultan Idris, 35900 Tanjong Malim, Perak, Malaysia

${ }^{3}$ Deparment of Chemistry Education, Faculty of Mathematics and Natural Science, Yogyakarta State University, Indonesia

${ }^{4}$ Department of Chemistry, Faculty of Mathematics and Natural Science, Universitas Negeri Padang, West Sumatera 25171, Indonesia

${ }^{5}$ Department of Chemistry, Faculty of Science, Khon Kaen University, Khon Kaen 40002, Thailand

*E-mail: illyas@fsmt.upsi.edu.my

doi: $10.20964 / 2019.11 .46$

Received: 5 July 2019 / Accepted: 20 August 2019 / Published: 7 October 2019

A multiwalled carbon nanotube paste electrode (MWCNTPE) modified with zinc aluminium layered double hydroxide-quinmerac ( $\mathrm{Zn} / \mathrm{Al}-\mathrm{LDH}-\mathrm{QM})$ was fabricated for simultaneous determination of uric acid and bisphenol A. This modified electrode was characterized by scanning electron microscope (SEM), transmission electron microscope (TEM), and electrochemical methods. Several experimental conditions such as percent of modifier, $\mathrm{pH}$ of the solution, and square wave voltammetry parameters were optimized. The effective surface area of the electrode were determined by chronocoulometry. There was several linear range where the sensor performs well which are within the concentration 0.3 $-30.0 \mu \mathrm{M}$ and $50.0-100.0 \mu \mathrm{M}$ for uric acid, and $0.3-50.0 \mu \mathrm{M}$ and $10.0-100.0 \mu \mathrm{M}$ for bisphenol A. The detection limit for both organics were $0.065 \mu \mathrm{M}$ and $0.049 \mu \mathrm{M}$, respectively. The modified MWCNTPE was also tested for the determination of uric acid and bisphenol A in real samples and achieved high recoveries percentage from $98.0 \%$ to $108.3 \%$.

Keywords: Layered double hydroxide, Modified electrode, Bisphenol A, Uric acid 
(C) 2019 The Authors. Published by ESG (www.electrochemsci.org). This article is an open access article distributed under the terms and conditions of the Creative Commons Attribution license (http://creativecommons.org/licenses/by/4.0/). 